\title{
Transmission of Special Autonomic Funds in the Economy through Mediation Variables
}

\author{
Sri Wulan Wijayanti, Abd. Jamal*, Putri Bintusy Syathi \\ Department of Economics, Faculty of Economics and Business, Syiah Kuala University, Darussalam, Banda Aceh, Indonesia
}

*Corresponding author email: abdjamal66@gmail.com

\begin{abstract}
This study analyzes the effect of special autonomy funds on physical infrastructure, education, health, and poverty as well as its effect on economic growth in Aceh Province. The effect seen is the direct or indirect effect that occurs between the realization of special autonomy funds on economic growth in Aceh Province. The physical infrastructure variables represented by the length of the road, education represented by the average length of schooling, health represented by life expectancy, and poverty represented by the percentage of poor population were intervening variables. The intervening variable is a variable that is considered capable of mediating between the independent variables and the dependent variable. The analysis model used in this study is path analysis so as to be able to see the direct and indirect effects of an independent variable on the dependent variable. The results found in this study are the realization of special autonomy funds has a direct effect on economic growth. While the indirect effect is given by the variable realization of special autonomy funds on economic growth through the length of the road, life expectancy, and the percentage of poor people. The variable of average length of schooling does not have an indirect effect between the realization of special autonomy funds on the economic growth of Aceh Province.
\end{abstract}

Keywords: Special Autonomy Funds, Physical Infrastructure, Education, Health, Poverty and Economic Growth

\section{Introduction}

The special autonomy funds are funds provided by the Government for a special region or special region with the aim of reducing inequality, poverty, and other regional problems. Special autonomy funds are only given to special areas such as Aceh Province, Yogyakarta Province, Papua Province, and West Papua Province. The distribution of allocations between one province and another varies from region to region. Meiyenti and Jitmau (2019) said that the distribution of special autonomy funds was carried out so that regions could regulate themselves more optimally after being given other balancing funds such as transfer funds, and so on. According to the Directorate of Regional Autonomy (2011) states that special autonomy funds are part of the transfer funds made by the central government to regional governments based on the mandate of the law of each region. For the Aceh Province region itself, special autonomy funds are given so that the Aceh Province remains within the Unitary State of the Republic of Indonesia (NKRI) and improves Aceh's welfare (Isa, 2014). The granting of special authority is expected to improve the community's economy in order to realize justice in the concept of regional product management, increase community welfare, and empower human resources (Iskandar, 2017).

The Special Autonomy Fund was given to the Aceh Province as compensation from the central government to the Acehnese people who were inseparable from the accumulation of conflicts over a period of 30 years. The conflict has put the people of Aceh in a tragic position. The impact generated by this prolonged conflict is not only in the economic field but also in other fields such as education, health and others. Therefore, the Aceh Province received a special policy by the constitution caused by injustice and a centralized form of government causing problems between the government of the Republic of Indonesia and the Free Aceh Movement so that a special autonomy policy emerged in the form of granting special autonomy funds through the Helsinki MoU in 2005 ('Ulya, 2015). This policy is expected to be a solution for Aceh Province to catch up with the development.

The provision of special autonomy funds also aims to reduce the development gap in various aspects between Aceh Province and other provinces in Indonesia as a result of the prolonged conflict. Some of the things that are the focus of development are poverty alleviation, improving the quality of human resources in Aceh Province, as well as infrastructure development that can support socio-economic and demographic activities in Aceh Province. This can be 
seen from the high poverty rate in Aceh Province in 2002 of 29.83\%, decreasing to $15.32 \%$ in 2019 after the provision of special autonomy funds (Central Bureau of Statistics of Aceh Province, 2020). In addition, limited access to safe education and health is also one of the causes of the lagging quality of human resources in Aceh Province compared to other provinces in Indonesia. Meanwhile, when viewed from the development sector, Aceh Province continues to show very significant developments after the granting of special autonomy funds.

The role of this special autonomy fund itself has a very dominant influence on development in Aceh Province. The proof can be seen from the Aceh Revenue and Expenditure Budget (APBA) where the special autonomy fund is one of the largest sources of funds for development in Aceh. Evaluation of the distribution of special autonomy funds and privileged funds is carried out regularly every year under the supervision of the Directorate General of Regional Autonomy. The control mechanism is that the regional government submits the first allocation realization report which will be examined by the Director General of Regional Finance at the Ministry of Home Affairs. Then the Director General of Regional Finance will provide recommendations to the Ministry of Finance as the State General Treasurer to disburse the funds.

Since the implementation of special autonomy, Aceh Province has received substantial regional funds, both from special autonomy funds and from additional oil and gas revenue-sharing funds (Abrara et al., 2020). In carrying out development, the management of the special autonomy fund and additional oil and gas revenue-sharing funds are mutually agreed upon between the Aceh Provincial government and the district/city governments in Aceh Province as mandated in Aceh Qanun No. 2 of 2008 concerning Procedures for Allocating Additional Oil and Gas Revenue Sharing Funds. Natural Gas and Use of Special Autonomy Funds. The province of Aceh itself was recorded from 2008 to 2019 to have received special autonomy funds of around 73.32 trillion rupiah. Based on Governor Regulation No. 79 of 2013 concerning Technical Guidelines for the Management of Additional Oil and Gas Revenue Sharing Funds and Special Autonomy Funds, it is explained that the use of special autonomy funds is focused on seven sectors, namely improving community welfare, including development and maintenance of infrastructure, people's economic empowerment, poverty alleviation, funding for education, health, social services, and the implementation of the privileges of Aceh.

Table 1 Budget and Realization of Special Autonomy Funds for Infrastructure Sector, Poverty Alleviation Sector, Education Sector, and Health Sector for Aceh Province 2016 - 2018 (Billion Rupiah).

\begin{tabular}{|c|c|c|c|c|c|c|c|c|c|}
\hline \multirow{2}{*}{ Sector } & \multicolumn{2}{|c|}{2016} & \multirow{2}{*}{$\%$} & \multicolumn{2}{|c|}{2017} & \multirow{2}{*}{$\%$} & \multicolumn{2}{|c|}{2018} & \multirow{2}{*}{$\%$} \\
\hline & Budget & Realization & & Budget & Realization & & Budget & Realization & \\
\hline (1) & (2) & (3) & (4) & (5) & (6) & (7) & (8) & (9) & (10) \\
\hline Infrastructure & 2,279 & 2,079 & 91.24 & 1,377 & 1,238 & 89.91 & 2,341 & 1.686 & 75.85 \\
\hline Alleviation & 74 & 73 & 98.02 & 196 & 153 & 78.08 & 421 & 43 & 10.31 \\
\hline Education & 942 & 780 & 82.77 & 1,299 & 1,088 & 83.71 & 1,056 & 827 & 78.35 \\
\hline Health & 666 & 634 & 95.24 & 926 & 836 & 90.20 & 890 & 829 & 93.13 \\
\hline
\end{tabular}

Source: Aceh Financial Management Agency (2019)

The government's budget from the special autonomy fund covers infrastructure, poverty alleviation, education, and health budgets. The highest budget each year is used for the construction and maintenance of infrastructure in the Aceh Provincial Government. In 2016 it was recorded at 2,279 trillion rupiah, increasing to 2,341 trillion rupiah in 2018. Likewise, the highest realization of the Aceh Province special autonomy fund is also for infrastructure development and maintenance. However, when viewed from the percentage of budget realization, the poverty alleviation sector is more optimal in maximizing the use of the budget. This can be seen in Table 1 where poverty alleviation was the highest realization in 2016 with a percentage of 98.02\%. In 2017 and 2018, the most optimal use of special autonomy funds was for the health sector with a percentage of $90.20 \%$ and $93.13 \%$, respectively.

Table 2 Average Growth Rate of Special Autonomy Fund, Length of Road, Average Length of Schooling, Life Expectancy, Poverty Percentage of Aceh Province in 2010 and 2019

\begin{tabular}{cccc}
\hline Sector & $\mathbf{2 0 1 0}$ & $\mathbf{2 0 1 9}$ & Average Growth Rate \\
\hline$(1)$ & $(2)$ & $(3)$ & $(4)$ \\
\hline Autonomy Fund & $2,236,969,200,000$ & $3,530,752,358,215$ & $6.43 \%$ \\
Length of Road & 1235.62 & 1519.56 & $2.55 \%$ \\
Average Length of Schooling & 8.28 & 9.18 & $1.21 \%$ \\
Life Expectancy & 69.08 & 69.87 & $0.13 \%$ \\
Poverty Percentage & 20.98 & 15.32 & $-3.00 \%$
\end{tabular}

Source: Aceh Financial Management Agency, and Central Bureau of Statistics of Aceh Province (2021) 
Table 2 shows the realization of special autonomy funds and the development of road lengths that have good conditions in Aceh Province. The average growth rate of the realization of the special autonomy fund budget each year is $6.43 \%$. The high rate of realization of the special autonomy funds provided did not have a significant impact on the length of roads in good condition in Aceh Province where the average growth rate of road lengths in good condition in Aceh Province was only 2.55\%. Based on Table 2, the special autonomy funds distributed tend to increase every year. However, this figure has not helped much to increase the average length of schooling (RLS) in Aceh Province. According to the Central Statistics Agency of Aceh Province (2019) during the period 2010 to 2019, the average rate of schooling for the population was only $1.18 \%$, while the average rate of special autonomy funds each year was $1.21 \%$. The very significant increase in special autonomy funds every year has not been able to produce a significant increase in the average length of schooling in Aceh Province (Maulana et al., 2020).

Meanwhile, if we look at the health sector, the variable life expectancy is not able to get an average growth rate that is faster than the average rate of increase in special autonomy funds. This is illustrated by the Life Expectancy (AHH) in Aceh Province where the average annual AHH growth in Aceh Province is only 0.13\% during the 2010 to 2019 period (Central Bureau of Statistics of Aceh Province, 2019). Meanwhile, health is one of the issues of the Sustainable Development Goals (SDGs) which is integrated into one goal, namely goal number three, which is to ensure a healthy life and promote well-being for all at all ages. This certainly makes Health as an indicator that gets important attention from both the central government and local governments.

In addition, the table above shows that the poverty alleviation budget has increased every year. However, this is not comparable to the poverty level in Aceh Province. According to Majid (2014), Aceh Province is one of the regions that has the seventh highest percentage of poor people at the national level, even though Aceh's APBD is in the third highest rank compared to 34 other provinces in Indonesia. In 2010, the national average percentage of poor people reached $14.44 \%$, much lower than the average poor population in Aceh province which was $21 \%$. Although in general the province of Aceh has succeeded in reducing the number of poor people from 2009 which reached $21.8 \%$ to $20.3 \%$ in 2010, the poverty rate in Aceh is still much higher, above the average poverty rate for the Indonesian population. According to the Central Statistics Agency (2020), the percentage of poor people in Aceh Province in 2019 reached $15.32 \%$ of the total population. The average rate of decline in the percentage of the poor in Aceh Province is $3 \%$ where this rate of decline is still not comparable to the special autonomy funds that have been issued with a growth rate of $6.43 \%$ for the period 2010 to 2019. The number of poor people in Aceh each year decreases disproportionately with the amount of special autonomy funds spent on poverty alleviation programs.

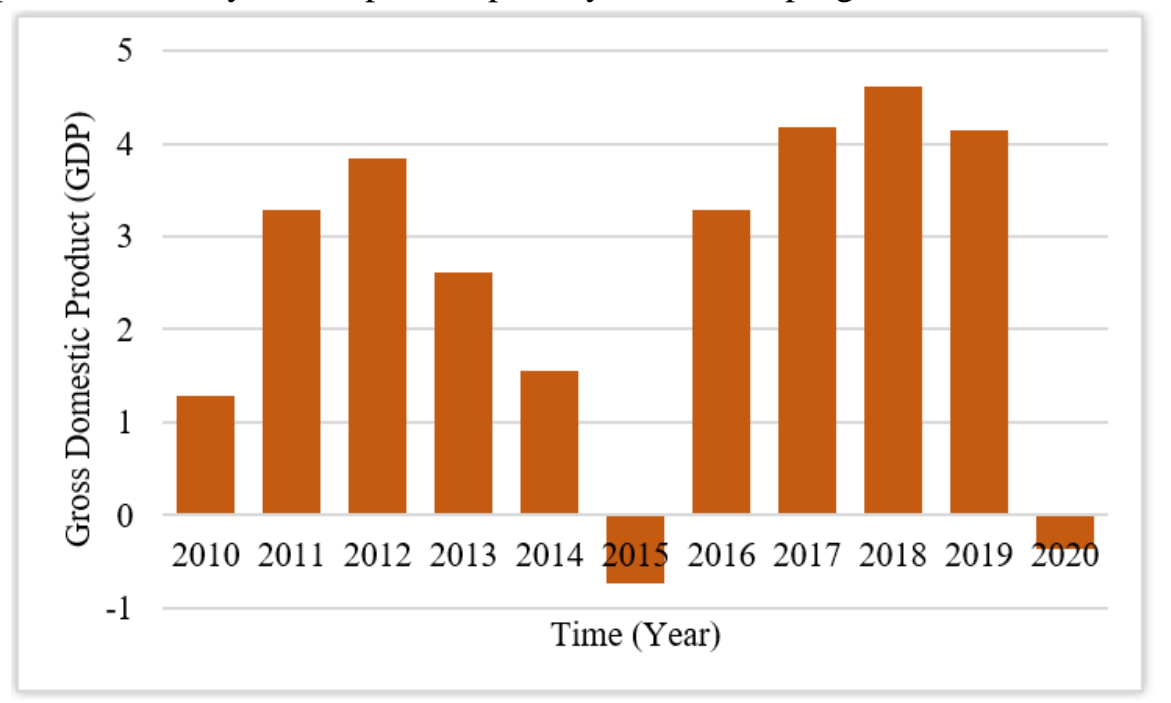

Figure 1 Aceh Province Economic Growth Rate 2010-2019 Period

The impact generated by the suboptimal growth of infrastructure, the average length of schooling, life expectancy, and the percentage of poverty have an impact on the rate of economic growth in Aceh Province. Figure 1 shows that economic growth in Aceh Province tends to fluctuate and even decline for 2 periods, namely in $2015(-0.73 \%)$ and $2020(-0.37 \%)$ due to the unstable world economy and the COVID-19 pandemic that hit Indonesia. The highest economic growth occurred in 2018 which was $4.61 \%$.

In a report on the study of the implementation of the Special Autonomy Fund in Aceh Province conducted by the World Bank (2011) concluded that the planning and budgeting of the special autonomy fund is one of the weaknesses in the management of the special autonomy fund. In recent years, the proposed programs and activities in the special autonomy plan have not fully addressed the development challenges. The special autonomy fund programs and activities in the health sector are also not fully based on needs. Aceh Province does not yet have a master plan that becomes the main reference in formulating plans and implementing development activities financed by the special autonomy fund.

Therefore, research is needed that can answer the influence given by special autonomy funds to directly increase the rate of economic growth in Aceh Province. In addition, this research is also to see the indirect impact given by 
special autonomy to increase the rate of economic growth in Aceh Province through the percentage of poor people, average length of schooling, life expectancy, and road infrastructure development.

\section{Literature Review}

Economic development in a region can be said to be successful or not based on economic growth indicators. Changes in output due to the process of economic development can be described by the increase in economic growth that occurs. Observation based on changes in output produced is one of the short-term economic analysis.

Several theories of economic growth put forward by economists among others:

1. Classical Economics

This theory emphasizes that economic growth that occurs in an area is caused by 4 factors, namely the population, the amount of capital goods stock, land area including natural wealth, and the level of technology used. However, of all these factors, the classical economists focused more on the rate of population growth with the assumption that land area and natural wealth were constant, and the level of technology did not change.

\section{Harrod-Domar}

Harrod-Domar's theory of economic growth emphasizes the importance of the role of investment to be able to support good economic growth. This theory uses several assumptions such as capital goods have full capacity, available savings are proportional to the value of national income, the ratio between capital and production is fixed value, and the economy that occurs only consists of 2 sectors, namely households and companies. The assumption illustrates that even though capital goods have reached their maximum capacity in a period, aggregate expenditure will cause an increase in the capacity of capital goods so that investments made in one period will increase the capacity of goods and services produced in the next period.

\section{Neo-Classical}

This theory is known as the Solow-Swan economic growth theory in accordance with the name of the originators, namely Robert Solow and Trevor Swan. This model is a development of the model proposed by Harrod-Domar with the addition of the second factor, namely labor and the inclusion of the third variable, namely the level of technology possessed into the economic growth equation. However, this theory assumes that the scale of returns generated by labor and capital inputs will continue to decrease if analyzed separately even though if analyzed simultaneously this theory also assumes a fixed return scale. This theory states that economic growth is strongly influenced by the production function. This makes production factors such as increased capital, improvement and improvement of the quality of labor, and technological progress are factors that can increase economic growth in a region.

The three theories are theories of economic growth that support economic growth based on the characteristics possessed by each region. However, the three theories argue that one of the important factors to increase economic growth is an increase in investment which can be in the form of government spending to spur economic growth in a region.

The special autonomy fund received by the Government of Aceh is a major factor in the ability of the Aceh Government's budget to finance and meet the funding needs of regional development. This is because the share given by the special autonomy funds to the total budget is relatively large. In addition, the special autonomy funds received by the Aceh Province have become a necessity to realize the activities related to special autonomy affairs which continue to grow. However, some facts occur that there are still various problems and obstacles in the implementation of development activities.

Warouw et al. (2016) in his research revealed that the special autonomy fund budget disbursed continues to increase but has not had a good impact on development and does not rule out future improvements by further developing and exploring quality resources in accordance with the mandate in the legislation. However, this is not in line with research conducted by Amelia and Ekobelawati (2018) by showing that funds transferred by the central government are directly transferred to districts/cities where any increase in these funds will increase GRDP.

In order to spur economic growth and improve people's welfare, it is necessary to allocate local government budgets that are in accordance with regional needs and on target. Allocating resources into the capital expenditure budget is a process fraught with political interests. This budget is intended to meet the public's need for public facilities and infrastructure provided by local governments. However, the political interest of the legislature involved in the budgeting process causes the allocation of capital expenditure to be distorted and often ineffective in solving problems in society (Keefer and Khemani, 2004).

The Ministry of Finance (2018) defines regional infrastructure spending as spending that is directly related to the acceleration of the development of public and economic service facilities in order to increase job opportunities, reduce poverty, and reduce the gap in the provision of public services between regions. Regional infrastructure expenditure is calculated from total capital expenditure and maintenance expenditure (excluding capital expenditure and maintenance for apparatus such as construction and/or maintenance of government buildings whose main function is for administrative services and official vehicles), and other expenditures that produce regional infrastructure.

One of the uses of special autonomy funds is intended to finance development, especially the construction and maintenance of infrastructure that comes from government spending or capital expenditures. In this study the authors use the length of the road as a physical form of infrastructure development in Aceh Province. This is inseparable from the large influence of road infrastructure on economic access between regions. Every road infrastructure development 
will expand market access and access to raw materials so that the overall economy between regions will be better and more productive.

In addition to physical infrastructure, other factors that become a priority for granting special autonomy funds in order to increase the rate of economic growth in Aceh Province are education and health. One indicator that can be used to see the success of the education sector is the average length of schooling. The higher the average length of schooling indicates the success of the education program, on the other hand, if the average length of schooling is lower, it indicates that the education program is less than optimal in terms of educating the nation. Meanwhile, to see the level of health in an area can be seen through the life expectancy indicator.

One of the problems that became the purpose of the special autonomy funds was the poor population which could hamper the rate of economic growth in Aceh Province. Therefore, the planned development program is not only based on infrastructure but also tries to make a program or breakthrough to reduce the poor population. Development that favors improving community welfare by the government needs to be improved, especially for the poor, because one of the indicators of community welfare in a country can be seen from the government's efforts to tackle poverty as reflected in the pro-poor budgeting of the government. . In the current era of government, the government's political will related to poverty reduction has begun to change along with the launching of Nawacita in the 2015-2019 RPJMN. The nine agendas (Nawa Cita) are a summary of the programs contained in the Vision-Mission of the President/Vice President.

Uddin et al. (2014) conducted a study entitled financial development and poverty reduction nexus: a cointegration and causality analysis in Bangladesh. The purpose of this study is to see the relationship between the development of development funds, economic growth, and poverty. This research uses cointegration and causality analysis. ARDL analysis results show that there is a positive relationship between budget and infrastructure development. In addition, infrastructure development has a negative and significant impact on poverty levels. These variables are also cointegrated over the long term and causality analysis shows that the Bangladeshi government can influence poverty reduction by encouraging the development finance sector. Faridi and Nazar (2013) with the research title Impact of fiscal autonomy on poverty in Pakistan. The purpose of this study is to evaluate the role of fiscal autonomy in reducing poverty in Pakistan. The method used in this research is OLS. The results show that provincial autonomy in spending and income on poverty has a significant and negative effect.

Zulham et al. (2015) in his research revealed that the percentage of poor people has not had a significant impact on the economy in North Sumatra Province. This finding is strengthened by research conducted by Maulana et al. (2020) which states that the percentage of the poor also does not have a significant influence on the rate of economic growth. Meanwhile, other variables such as the average length of schooling, life expectancy, and special autonomy funds have a significant positive influence on the rate of economic growth in Aceh Province. However, there is still little research related to the effectiveness of the allocation of special autonomy funds for the purpose of providing these funds. Therefore, this study examines the effects of the special autonomy funds on the rate of economic growth directly or indirectly through road infrastructure, life expectancy, average years of schooling, and poverty levels in Aceh Province. As for summarizing the description, a framework of thought as seen in Figure 2.

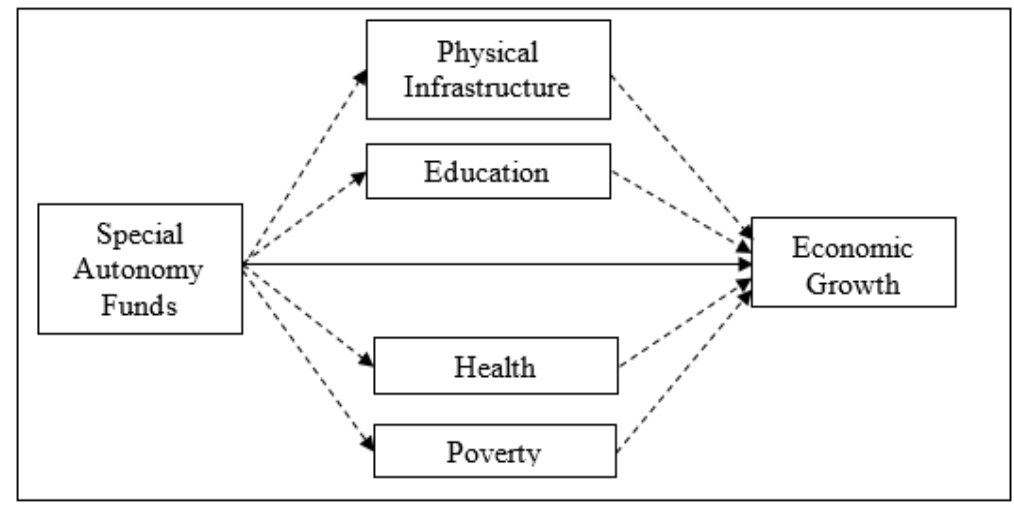

Figure 2 Research Framework

\section{Materials and Methods}

\subsection{Materials}

In this study, the variable that explains the rate of economic growth is the management of special autonomy funds. In addition, this study also looks at the indirect effect generated by the management of special autonomy funds on the rate of economic growth through physical infrastructure, education and health as well as poverty. Physical infrastructure is meant here is government spending on infrastructure in the form of hard infrastructure (Physical Hard Infrastructure) which is most closely related to the public interest of the community, namely the length of the road. Furthermore, which represents the education indicator is the average length of schooling while the health indicator is represented by life expectancy. Meanwhile, the poverty factor is represented by the percentage of poor people. The 
data used in this study is panel data consisting of time series data for the period 2013-2020 and cross section data covering 23 districts/cities in Aceh Province. The type of data used in this study is secondary data obtained from BPS Aceh, BPKA, Bappeda, Ministry of Finance, and other agencies related to this research. The data used in this study are the realization of special autonomy funds, the length of the road, the average length of schooling, life expectancy, the percentage of poverty, and the rate of economic growth.

\subsection{Methods}

The analytical method used is inferential analysis using path analysis or path analysis which has several advantages such as being able to see the direct or indirect effect of each exogenous variable on endogenous variables caused by cause-and-effect relationships based on mediating variables. Path analysis uses correlation, regression and paths that are owned based on the relationship between variables so that direct and indirect effects can be known through mediating variables. Shen et al. (2021) say that the path analysis model aims to analyze the relationship between exogenous and endogenous variables in order to determine the direct or indirect effect.

\section{Results and Discussion}

The purpose of granting special autonomy funds in general is to improve the welfare of the people of Aceh Province through improving the quality of education and health as a result of the prolonged conflict that occurred. The provision of these funds is expected to be able to catch up with the quality of human resources in Aceh Province compared to human resources in other regions. In addition, the granting of special autonomy funds in Aceh Province aims to reduce poverty and improve infrastructure in Aceh Province. This is expected to increase economic growth in Aceh Province in the future. This study divides these paths into 5 regression models. The results of the regression can be seen in Table 3.

Table 3 Result of Panel Regression

\begin{tabular}{|c|c|c|c|c|c|c|c|}
\hline \multirow[b]{2}{*}{ Model } & \multirow[b]{2}{*}{$\begin{array}{l}\text { Dependent } \\
\text { Variable }\end{array}$} & \multicolumn{6}{|c|}{ Coefficient of Independent Variable } \\
\hline & & $\begin{array}{c}\text { Percentage of } \\
\text { Poor } \\
\text { Population }\end{array}$ & $\begin{array}{l}\text { Average } \\
\text { Length of } \\
\text { Schooling }\end{array}$ & $\begin{array}{c}\text { Life } \\
\text { Expectancy }\end{array}$ & Road Length & $\begin{array}{c}\text { Realization } \\
\text { of Special } \\
\text { Autonomy } \\
\text { Fund }\end{array}$ & $\begin{array}{c}\text { The Best } \\
\text { Model }\end{array}$ \\
\hline$(1)$ & $(2)$ & (3) & (4) & $(5)$ & & & \\
\hline 1 & $\begin{array}{c}\text { Realization } \\
\text { of Special } \\
\text { Autonomy } \\
\text { Fund }\end{array}$ & $(0.003004)^{*}$ & - & - & - & - & $\begin{array}{c}\text { Random } \\
\text { effect } \\
\text { model }\end{array}$ \\
\hline 2 & $\begin{array}{c}\text { Realization } \\
\text { of Special } \\
\text { Autonomy } \\
\text { Fund }\end{array}$ & - & $(0.002244)^{*}$ & - & - & - & $\begin{array}{l}\text { Fixed } \\
\text { effect } \\
\text { model }\end{array}$ \\
\hline 3 & $\begin{array}{c}\text { Realization } \\
\text { of Special } \\
\text { Autonomy } \\
\text { Fund }\end{array}$ & - & - & $(0.002756)^{*}$ & - & - & $\begin{array}{c}\text { Random } \\
\text { effect } \\
\text { model }\end{array}$ \\
\hline 4 & $\begin{array}{c}\text { Realization } \\
\text { of Special } \\
\text { Autonomy } \\
\text { Fund }\end{array}$ & - & - & - & $0.328610^{*}$ & - & $\begin{array}{l}\text { Random } \\
\text { effect } \\
\text { model }\end{array}$ \\
\hline 5 & $\begin{array}{l}\text { Realization } \\
\text { of Special } \\
\text { Autonomy } \\
\text { Fund }\end{array}$ & $0.163075^{*}$ & 0.364273 & $(0.692970)^{*}$ & $(0.056721)^{*}$ & $0.054468^{*}$ & $\begin{array}{l}\text { Fixed } \\
\text { effect } \\
\text { model }\end{array}$ \\
\hline
\end{tabular}

Table 3 indicates the realization of special autonomy funds has a negative and significant effect on the percentage of poor people. This negative effect shows that an increase in the realization of special autonomy funds by 1 billion has succeeded in reducing the percentage of poor people by $0.003 \%$. This is in accordance with research conducted by Ikhsan (2015) which states that the realization of special autonomy funds has succeeded in reducing the percentage of the poor. Next is the effect given by the realization of special autonomy funds on the average length of schooling in Aceh Province. The given effect is statistically significant but has a negative direction. Every 1 billion rupiah increase 
in the realization of special autonomy funds will reduce the average length of schooling in Aceh Province by $0.002 \%$. This is inseparable from the high educational gap obtained between regions in Aceh Province. The Central Statistics Agency for Aceh Province (2020) states that there is a high average length of schooling gap, namely the Banda Aceh City area has an average length of schooling of 12.65 years in 2020 while the area with the smallest average length of schooling is Subulussalam City. that is equal to 7.84 years.

The next regression model illustrates the effect given by the realization of special autonomy funds on the life expectancy of the people of Aceh Province. The given effect has a negative direction and is statistically significant. Each increase in the realization of special autonomy funds by 1 billion rupiah can reduce life expectancy by $0.003 \%$. This influence is also caused by the gap in health access between regions in Aceh Province. Based on data from the Central Statistics Agency (2020) shows that the highest number of hospitals is owned by the City of Banda Aceh as many as 12 hospital units while many regions in Aceh Province only have 1 hospital unit per district/city. This gap causes many people in Aceh Province to find it difficult to get access to better health. This result is also in accordance with the results of research conducted by the National Team for the Acceleration of Poverty Reduction (2020) where there is still a relatively high difference between the demand for health facilities and the availability of health facilities between regions in Aceh Province.

The next effect is given by the realization of special autonomy funds on the length of roads in Aceh Province. The realization of special autonomy funds has a positive and significant impact on the length of roads in Aceh Province. Every 1 billion increase in the realization of special autonomy funds can increase the length of roads by $0.329 \%$ of the length of roads in Aceh Province. This finding is in line with the research conducted by Putra (2014) where the granting of special autonomy funds had a major impact on improving infrastructure in general in Aceh Province. The last model used to complete the path analysis shows that the variable percentage of poor people and special autonomy funds have a significant influence on the rate of economic growth in Aceh Province. The variables of road length and life expectancy have a negative and significant effect on the rate of economic growth in Aceh Province. Meanwhile, the variable of average length of schooling does not have a statistically significant effect on the rate of economic growth in Aceh Province.

The variable percentage of the poor population has a positive and significant effect on the rate of economic growth. Every $1 \%$ increase in the poor will increase the rate of economic growth by $0.163 \%$. This is contrary to the theory which states that a decrease in the percentage of poor people will increase the rate of economic growth. This influence occurs due to the high labor force in the agricultural sector. In 2020, the agricultural sector contributed $36.49 \%$ of the total workforce in Aceh Province. While most workers in the agricultural sector are farm laborers. Based on data from the Central Statistics Agency for Aceh Province (2020) it is stated that farm laborers in Aceh Province are 34.25\% of the total agricultural workers. This finding is in accordance with the results of research conducted by Maulana et al. (2020) where the percentage of the poor has a positive influence on improving the economy due to the high economic inequality that occurs so that the formed economy cannot be felt by people who are classified as poor.

The variable average length of schooling does not have a statistically significant effect on the rate of economic growth in Aceh Province even though it has a positive coefficient. The high inequality in access to education that can be felt between regions is one of the factors causing the insignificant average length of schooling on the rate of economic growth. In addition, the low educational qualifications for various employment opportunities in many regions in Aceh Province contribute to the insignificant effect of the average length of schooling in Aceh Province. Much of the workforce in Aceh Province is in the agricultural sector which does not have to have a certain level of education qualification. The results of this study are in line with the results of research conducted by Majid (2014) where the educational gap between regions in Aceh Province is still relatively high due to the lack of quality teachers between regions and the uneven development of the education sector between regions in Aceh Province.

The next variable is life expectancy which has a negative and significant effect on the rate of economic growth in Aceh Province. Every 1\% increase in life expectancy will reduce the rate of economic growth in Aceh Province by $0.693 \%$. This finding is not in accordance with the theory which states that improving human resources through increasing life expectancy will increase the rate of economic growth in a region. This is triggered by the difficulty of access to health that can be obtained by many people in Aceh Province. The limited number of doctors and the number of hospitals in many regions compared to the provincial capitals is one of the reasons for the inappropriate direction given by this variable to the rate of economic growth. This finding is in accordance with the results of a report conducted by the National Team for the Acceleration of Poverty Reduction (2020) where there is still a gap between the availability of doctors and hospital beds and the demand for doctors and hospital beds between regions in Aceh Province.

The next effect is given by the road infrastructure variable which has a negative and significant effect on the rate of economic growth in Aceh Province. Every 1-kilometer increase in road infrastructure can reduce the economic growth rate of Aceh Province by $0.057 \%$.

The last variable studied is the realization of special autonomy funds which have a positive and significant effect on the rate of economic growth in Aceh Province. Every 1 billion rupiah increase in the realization of special autonomy funds can increase the rate of economic growth by $0.054 \%$. This finding is in accordance with the research conducted by Maulana et al. (2020) where the rate of economic growth can be boosted by increasing the realization of special autonomy funds in Aceh Province. In addition, the increase in the realization of special autonomy funds is able to accelerate income equality between regions in Aceh Province. After analyzing the direct effect, then an 
analysis of the indirect effect provided by the realization of special autonomy funds on the economic growth rate of Aceh Province is carried out through the percentage of poor people, average years of schooling, life expectancy, and length of roads. The indirect effects given by each of these variables can be seen in Figure 3.

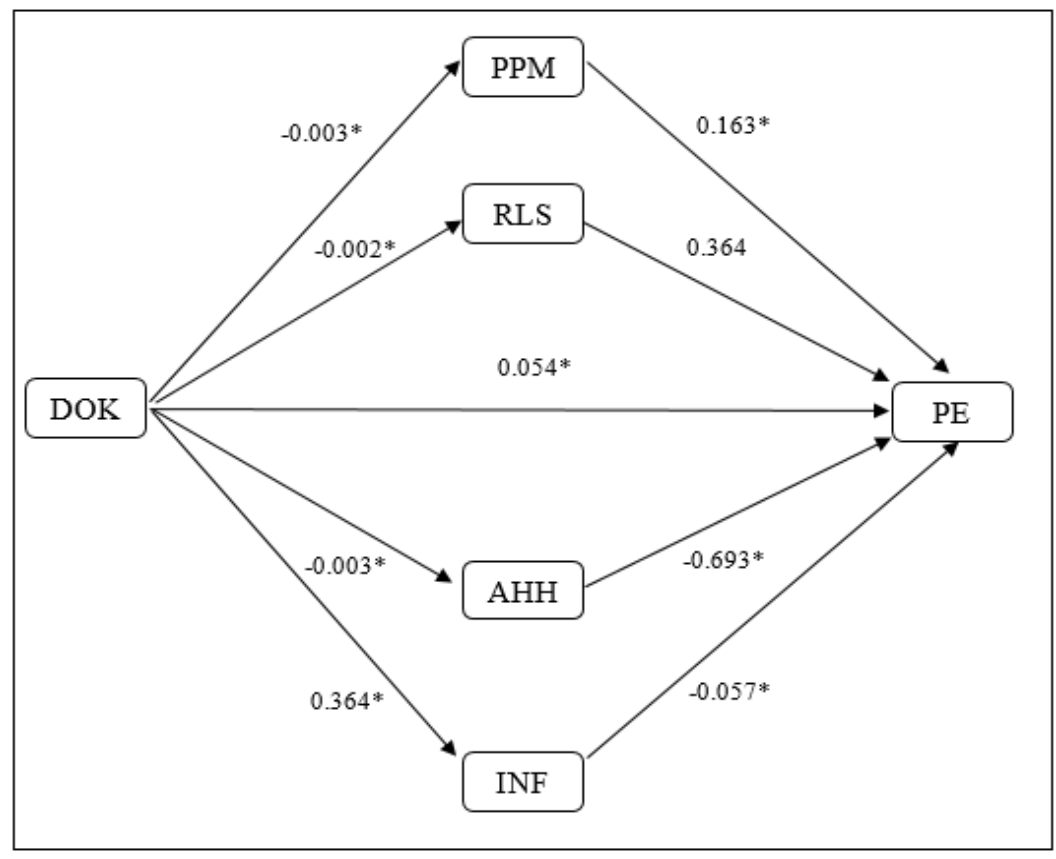

Figure 3 Result of Path Analysis

Where;

DOK: Realization of Special Autonomy Fund,

PPM: Percentage of Poor Population,

RLS: Average Length of Schooling,

AHH: Life Expectancy,

INF: Road Length,

PE: Economic Growth

In Figure 3, the result displays the realization of special autonomy funds has a significant effect on the economic growth rate of Aceh Province through the percentage of poor people of $(-0.003) \times 0.163=-0.001 \%$. This illustrates that every increase in the realization of special autonomy funds by 1 billion rupiah will reduce the rate of economic growth through road infrastructure by $0.001 \%$. The realization of special autonomy funds does not significantly affect the economic growth rate of Aceh Province through the average length of schooling. The realization of special autonomy funds has a significant effect on the economic growth rate of Aceh Province through a life expectancy of ($0.003) \times(-0.693)=0.002 \%$. These results indicate that an increase in the realization of special autonomy funds by 1 billion rupiah can increase the rate of economic growth in Aceh Province through a life expectancy of 0.002\%.

The realization of special autonomy funds has a significant effect on the economic growth rate of Aceh Province through road infrastructure by $0.364 \times(-0.057)=-0.021 \%$. Each increase in the realization of special autonomy funds by 1 billion rupiah will reduce the rate of economic growth in Aceh Province through road infrastructure by $0.021 \%$. Based on these results, it can be seen that the total indirect effect given by the realization of special autonomy funds on the economic growth rate of Aceh Province through the percentage of poor people, average length of schooling, life expectancy, and road infrastructure is $(-0.001)+0.002-0.021=-0.02 \%$. These results indicate that every 1 billion increases in the realization of special autonomy funds can indirectly reduce the economic growth rate of Aceh Province by $0.02 \%$. Meanwhile, if we look at the total effect given by the realization of special autonomy funds on the economic growth rate of Aceh Province, it is $0.054-0.020=0.034 \%$. This shows that in total each increase in the realization of special autonomy funds by 1 billion rupiah can increase the rate of economic growth by $0.034 \%$. After analyzing using the path model, then proceed with the Sobel test. The Sobel test aims to see whether the variables used are appropriate to mediate between the realization of special autonomy funds and the economic growth rate of Aceh Province. The results obtained in the Sobel test can be seen in Table 4. 
Table 4 Result of Sobel Test

\begin{tabular}{lcl}
\hline \multicolumn{1}{c}{ Intervening Variables } & Prob & \multicolumn{1}{c}{ Decision } \\
\multicolumn{1}{c}{$(1)$} & $(2)$ & \multicolumn{1}{c}{$(3)$} \\
\hline Realization of Special Autonomy Fund & $0.06724057^{*}$ & Fit as an intervening variable \\
Average Length of Schooling & 0.11966746 & Not fit as an intervening variable \\
Life Expectancy & $0.07937799^{*}$ & Fit as an intervening variable \\
Road Length & $0.00171925^{*}$ & Fit as an intervening variable \\
\hline
\end{tabular}

Note: * Significant at $5 \%$ alpha

The results of the Sobel test in Table 4 showed that only the average length of schooling was not statistically significant to be an intervening variable. Meanwhile, the variables of the percentage of poor people, life expectancy, and road length can indirectly mediate between the realization of special autonomy funds and the economic growth rate of Aceh Province. The findings of the Sobel test are in accordance with the results of the path analysis which shows that only the average length of schooling cannot provide an indirect effect between the realization of special autonomy funds on the rate of economic growth in Aceh Province.

\section{Conclussion}

Based on the results and discussions that have been discussed previously, there are several conclusions that can be summarized in this study as follows:

1. Path analysis of the panel data that is formed shows every influence given by each independent variable on the dependent variable, both direct and indirect effects where the resulting direct effects are:

a. The variable realization of special autonomy funds has a direct positive and significant effect on road infrastructure and the rate of economic growth in Aceh Province. In addition, the realization of special autonomy funds has a negative and significant effect on the average length of schooling, life expectancy, and the percentage of poor people in Aceh Province during the study period.

b. Road infrastructure variables and life expectancy have a direct and significant negative effect on the rate of economic growth in Aceh Province. The percentage of poor people has a positive and significant direct influence on the rate of economic growth in Aceh Province. Meanwhile, the average length of schooling has no statistically significant effect on the rate of economic growth in Aceh Province during the study period.

2. The effect of the realization of special autonomy funds on the rate of economic growth indirectly is that the realization of special autonomy funds has a significant and indirect negative effect on the rate of economic growth in Aceh Province through the percentage of poor people and road infrastructure. In addition, the variable realization of special autonomy funds has an indirect and significant positive influence on the rate of economic growth in Aceh Province through life expectancy. Furthermore, the realization of special autonomy funds does not have a significant indirect effect on the rate of economic growth in Aceh Province through the average length of schooling.

3. In total, the realization of special autonomy funds has a positive and significant impact on the rate of economic growth in Aceh Province during the research period.

\section{References}

Amelia, \& Ekobelawati, F. (2018). Efektifitas Transfer Pusat Terhadap Perekonomian Kalimantan Barat. Jurnal Buletin Studi Ekonomi, 23(1), 124-137.

Abrara, M., Juandab, B., Firdausc, M., \& Hakimd, D. B. (2020). The Impact of Special Autonomy Funds on Poverty of Human Development and Unemployment in Aceh. International Journal of Innovation, Creativity and Change, 12(10), $713-734$.

Faridi, M. Z., \& Nazar, R. (2013). Impact of Fiscal Autonomy on Poverty in Pakistan. Pakistan Journal of Commerce and Social Sciences, 7(1), 141-156.

Isa, A. G. (2014). Implementation of Islamic Shariah in Special Autonomy: A Case of Aceh Province. Miqot: Jurnal Ilmu-ilmu Keislaman, 38(1), 119-134.

Iskandar, I. (2017). Effect of human development index fund on economic growth through a special autonomy. Jurnal Ekonomi Pembangunan: Kajian Masalah Ekonomi dan Pembangunan, 18(1), 40-49.

Ikhsan. (2015). Relasi Otonomi Khusus dan Pengurangan Kemiskinan di Provinsi Aceh. Jurnal Universitas Teuku Umar, 148, $148-162$. 
Keefer, P., \& Khemani, S. (2005). Democracy, public expenditures, and the poor: understanding political incentives for providing public services. The World Bank Research Observer, 20(1), 1-27.

Majid, M. S. A. (2014). Analisis Tingkat Pendidikan Dan Kemiskinan Di Aceh. Jurnal Pencerahan, 8(1), $15-37$.

Maulana, A. R. R., Zulham, T., \& Sartiyah. (2020). Aceh Province Economic Convergence Determination. International Journal of Business, Economics and Social Development, 1(4), 212-226.

Meiyenti, I., \& Jitmau, A. (2019). Optimalisasi Penggunaan Dana Otonomi Khusus dalam Program Pembangunan Rumah Layak Huni di Distrik Kuala Kencana Kabupaten Mimika Provinsi Papua. Jurnal Ilmu Pemerintahan Widya Praja, 45(1), 71-84.

Peraturan Gubernur No.79 Tahun 2013 Tentang Petunjuk Teknis Pengelolaan Tambahan Dana Bagi Hasil Minyak dan Gas Bumi dan Dana Otonomi Khusus, Pub. L. No. No.79 Tahun 2013 (2013).

Putra, E. J. (2014). Mewujudkan Kesejahteraan Melalui Dana Otonomi Khusus Aceh dalam Perspektif Hukum Keuangan Negara. Kanun Jurnal Ilmu Hukum, 64, 421-435.

Qanun Aceh No.2 Tahun 2008 tentang Tata Cara Pengalokasian Tambahan Dana bagi hasil Minyak dan Gas Bumi dan Penggunaan Dana Otonomi Khusus, Pub. L. No. No. 2 Tahun 2008, 1 (2008).

Shen, H., Zheng, S., Xiong, H., Tang, W., Dou, J., \& Silverman, H. (2021). Stock market mispricing and firm innovation based on path analysis. Economic Modelling, 95, 330-343.

Uddin, G. S., Shahbaz, M., Arouri, M., \& Teulon, F. (2014). Financial Development and Poverty Reduction Nexus: A Cointegration and Causality Analysis in Bangladesh. Economic Modelling, 36, 405-412.

Ulya, Z. (2015). The Interpretation of Helsinki Memorandum of Understanding on The Issue of Aceh's Special Autonomy in Relation to Political Rights. Journal Yudisial, 8(2), 125-143.

Warouw, S., Nangoy, G., \& Runtu, T. (2016). Analisis Penggunaan Dana Otonomi Khusus Pada Pemerintah Kota Sorong di Provinsi Papua Barat. Jurnal Berkala Ilmiah Efisien, 16(01), 627-637.

World Bank, Universitas Syiah Kuala, \& Universitas Malikussaleh. (2011). Kajian Pengelolaan dan Pemanfaatan Dana Otonomi Khusus Aceh.

Zulham, T., Muhammad, S., Masbar, R., \& Sirojuzilam. (2015). The Impact of Special Autonomy on the Convergence of Regional Economic Growth in Aceh, Indonesia. Aceh International Journal of Social Science, 4(1), 41-55. 